\title{
GEOGRAPHIC DISTRIBUTION OF NEUROPTEROID INSECTS, WITH AN ANALYSIS OF THE AMERICAN INSECT FAUNA.
}

By Nathan Banks.

It is usual in general works on distribution to consider insects as widely dispersed by winds, and sea-currents, and therefore of little use in geographic studies. But every entomologist knows that the great majority of insects are more circumscribed in distribution than many of the higher animals. There are many insects of as wide distribution as the human species, but for each of these there are thousands that are confined to a very restricted range. Of our 15,000 known species of beetles only 500 or 600 are also known from Europe. Many of these belong to a few families of particularly northern distribution, many are accidental captures, and many have been introduced by commerce. Insects, when properly investigated, are just as useful in studying distribution as any other animals.

It has been remarked that there are two principal viewpoints from which to study geographic distribution. One is to consider what animals inhabit each country, and from these facts divide the world into a series of regions, subregions, etc. This, the static method, is, to my mind, extremely useful, and has been utilized by many, and may be followed to much advantage. It presents the facts that are to be accounted for by our theories. The other viewpoint is how the fauna of a country came to be what it is; an attempted explanation of its various elements. This, the dynamic study of distribution, depends largely upon geology, palæontology, and upon philosophic considerations regarding the origin, habits, and means of dispersal of the various groups of animals. In reality these two viewpoints are the beginning and end of the same thing.

From this dynamic viewpoint one sees that the insect fauna of a country, as the United States for example, is partly due to what it has inherited from previous land-masses in this vicinity, partly to what has migrated to it in ancient times, and partly to what has reached it since the continents have existed in their present form. 
An insect that belongs to a country through inheritance, and one that it obtains through migration or dispersal, each may spread over that country and exist side by side; or each may be restricted to a very narrow range. The many cases of insect introduction in historic times show that great numbers of insects not now occurring here, could live and thrive with us.

The various orders, families, and genera of insects did not originate at the same time and place. The place of origin, and the changes that have elapsed since their origin have a definite bearing on their distribution today. Most divergent views of the relationship of certain faunas are often expressed by students who consider different groups. For example the Panorpid fauna of the United States would show that the Eastern United States is closely related to Europe, while the Raphidiidæe would show that it is the Western United States that is related to Europe. Again the large and rather recent family of butterflies, Heliconidæ, are only neotropic; while the ancient, small, family Sialidæ are of world-wide occurrence. The explanation must be in the different time and place of origin of these groups, and the continental changes that have aided or barred their dispersal.

From a.study of mammals and birds zoologists divide up the world into several zoological realms, whose outlines agree fajrly well with those of the continents; thus we have an African, Australian, South American, Malayan, Indian, and Holarctic realms; the latter for Europe and North America. With insects this is not so. Several, probably all, of the continents possess elements showing relationship to other regions, derivatives of a fauna more fully developed elsewhere, and indicating that insect distribution is much older than the present form of the continents. Thus the Nearctic part of the Holarctic realm. is not a unit, but a commingling of natives and immigrants from times long before there were any mammals.

New Zealand has been included in the Australian realm, yet the insect fauna of New Zealand is more foreign to Australia than to America. Moreover, Australia presents at least two very different series of insects, one similar to that of Europe or at least. to the fossil insects of Europe, and the other a series of peculiar, often primitive forms entirely unlike the European insects. 
Since the main orders of insects have existed on this earth the gross outlines of continents have changed several times, and between these changes there were migrations and dispersals, just as there is today. So that today each continent has insects which by their structure and origin are isolated from the other insects around them and find their relations only to insects of distant countries.

The striking cases of discontinuous distribution have to me a most significant importance; I hardly think that their value has ever been sufficiently appreciated by the student of geographic distribution.

A few years ago I stood in an isolated valley in Western North Carolina. About me were flying several species of Panorpa and a Bittacus, Panorpids which are widely distributed in the Eastern United States, not one of which occurs in the Western States. Yet right with these Panorpids was another, a species of Panorpodes, a genus whose only other known habitat is Oregon and Japan. In that same valley are many spiders, nearly all of which are common over much of the Eastern United States, but yet there, and in several nearby places in the Southern Appalachians, is a curious spider, Hypochilus. Where else does it occur? In Colorado, and a closely allied genus in North China, and one in New Zealand. Hypochilus, and its related genera are the only known members of what is structurally the most isolated family of spiders. Panorpodes is also a very distinct genus and less specjalized than the other Panorpid genera around it.

These two cases are but samples of a long list of insects (and also plants) that show a relationship of our Alleghanies with the Northwest, and with Japan and North China. How did it happen? I doubt if you can find a single genus of insects which is now known only from the Southern Appalachians and say from Eastern Brazil, or West Africa; regions no more distant than Japan. Why are there not such cases?

Consider another series of cases. In Eastern South America, in Argentine, and parts of the Andean region there are several species of a genus of handsome antlion flies, Dimares. It is structurally very unlike anything else in South America. Yet in South Africa, in Arabia, in Ceylon are species of another genus Echthromyrmex, so similar to Dimares, that one is loathe 
to separate them. Both have a venational peculiarity unknown in all other Myrmeleonidæ. Another genus, Creagris, common in Africa and India, even to Australia, is represented in South America by Dimarella, which possesses the same structural peculiarities, otherwise unknown in the family. One of the most distinct genera of the Chrysopidæ is Apochrysa. It occurs in Australia, Insulinde, Ceylon, Africa and Eastern South America up into Central America. A distinct genus of caddice flies, Leptonema, common in South America, occurs elsewhere only in Africa and Ceylon. The Oestropsychid caddice flies, of which there are five genera, have a similar distribution, one genus in Insulinde, three both Indian and African, and one Brazilian. The restricted genus Embia, abundant in Africa, has several species in Brazil. The peculiar Oligoneurine mayflies are known from Southern Europe, Africa, Northern South America, Central America and West Indies. These instances from the Neuropteroid insects can be duplicated in other orders of insects. What does this relation between South America and parts of Africa and India mean?

Consider a third series of cases. Again and again entomologists have called attention to the fact that many structurally isolated Australian and New Zealand insects find their nearest counterpart in certain Chilian forms. This is as noticeable in the Neuropteroid insects as in other orders. The curious Australian Perlid genus, Eusthenia, is closely related (as far as existant forms are concerned) only to the Chilian genus, Diamphipnoa. Stenosmylus occurs only in Australia, New Zealand, and Chili; Psilochorema only in Chili and New Zealand; the Chilian Mantispid, Drepanicus, is most closely related to the Australian genus, Ditaxis. The termite, Porotermes, is from Chili, Australia, Tasmania, and South Africa. There surely must be a reason for this distribution.

There are still other series of cases of widely discontinuous distribution. One is the similarity between certain insects of Patagonia, the Straits, Falkland Islands, etc., and insects of Europe and North America. The Limnephilid caddice flies are almost wholly Holarctic in distribution, and constitute a large share of our Trichopterous fauna. One or two reach North Africa and Mexico. In the tropics there are none, but in this Patagonian region they reappear in genera the same or closely 
similar to our own. The same can be said of other insects; in Carabidæ Pycnochila and Omalium are such examples. Mabille reporting on Lepidoptera from Terra del Fuego and Cape Horn, remarks on the likeness of that fauna to the European and North American. Elwes has noted the same thing in butterflies.

Another series of cases represent the relationship of the insects of the Madeira and Canary Islands to those of the Mediterranean region. This has been extensively studied by Wollaston and Murray for the Coleoptera, and the Neuroptera, though not so fully known from the islands, tell the same story.

A series of cases, familiar to us, of discontinuous distribution, are those due to the advance and subsequent retreat of the ice-cap. The cases of butterflies and other insects and spiders stranded on the tops of various mountains are well known; and it should be noted that living with these stranded insects are many others that occur all over the neighboring country. The Holarctic insect fauna includes hundreds of cases of discontinuous distribution; species the same or closely allied in North America and Europe. These are usually cases of divergent evolution, since in nearly all cases a close comparison shows that they differ slightly in structure, or color, or habits.

After one is familiar with the appearance of the insects of the United States and begins to examine exotic forms, he naturally compares them with those of this country, or of Europe, whose fauna is well-known.

The Neuropteroid insects that I have seen from South America frequently fall into our genera or are closely related thereto. Certain Chilian forms, and a few others like Apochrysa, Dimares, etc., look foreign. When I examine the Neuroptera of Japan and India the same idea appeals to me-how many are closely similar to our own. Here and there, as Perissoneura of Japan, and Palpares in India, are foreign forms. When I consider the Australian Neuropteroids I see also a number that are strikingly like those of the United States. Even frail and isolated genera, as example Sisyra, occur in closely allied species right through from United States, Europe, India, Japan, Insulinde, and to Australia. But with these familiar insects are many that are widely different from our own.

This foreign element that I notice in South America, in India, in Australia is the typical African Neuropteroid fauna. 
When I examine the Neuropteroid insects from tropical and South Africa and Madagascar, I see that a large part are strange to me. That where genera are the same, they are usually worldwide, and that many of our typical forms are wholly unrepresented in Africa.

The points wherein Australia differs from the United States are in many cases just the points wherein Australia agrees with Africa and Ceylon.

For example, Psychopsis, a remarkable Hemerobiid that forms a tribe or subfamily by itself occurs in several species in Australia, East Africa and India. Ankylopterus, Protoplectron, Lysmus, Creagris, Nesoleon, Atalophlebia, Notanitolica, Dipseudopsis Periclystus, Suhpalasca, etc., all show the relation of Africa, India, Malasia, and Australia. Various other genera connect Africa and India as Palpares, and Tomatares. Similar striking insects in other orders indicate the same relationship.

There is, therefore, broadly speaking but three types of insect fauna, as already noted by Murray. One, the Microtypal, includes many of the insects of Europe and North America, and Northern Asia, a considerable element in Andean America, many in India and Insulinde, and New Zealand, a district representation in Australia, but very poorly developed in Africa.

Another fauna is the African or Gondwandan; it embraces many of the forms most peculiar to us. Its present home is Africa, but strong in Australia and almost as strong in Insulinde and Ceylon, plainly present in India, and noticeable in South America through various isolated genera. We may mention some of the peculiarities of this Gondwandan fauna in Neuropteroids. There are no Limnephilid, nor Rhyacophilid caddiceflies, no Raphidia, no Panorpa, no Sialis, in fact many of our common genera are there represented by different genera.

And third, is the Brazilian fauna, a more recent development; this does not appear so distinct in the Neuroptera as in the Lepidoptera, but we may cite Allochrysa Callibcetis, Haploglenius, Ululodes (and allied genera), Trichoscelis, Campsurus, Euthyplocia, Thrysophorus, Blepharopus, Phylloicus, Marilia.

It is so customary to consider New Zealand as part of the Australian realm that I desire to express as strongly as possible that as far as their insect fauna is concerned Australia and New Zealand are much more related to other parts of the world than 
to each other. Sharp says "The Coleopterous fauna of New Zealand seems to have most affinity with that of Chili and Patagonia, and but little with that of the Australian fauna." Meyrick holds that for the Lepidoptera "New Zealand is utterly different from Australia." The Neuroptera show the same differences.

New Zealand lacks all the peculiar, primitive or synthetic Neuroptera such as Ithone, Eusthenia, Nymphes, Stilbopteryx, Mastotermes, Plectrotarsus, etc., that occur in Australia. There are no Ascalaphidæ in New Zealand, many in Australia, no Mantispidæ in New Zealand, many in Australia, only one (an separate genus) of Myrmeleons in New Zealand, many in Australia. Among the true Neuroptera Stenosmylus occurs in Australia and New Zealand, but also in Chili. New Zealand is remarkable for its Trichopterous fauna. At least 15 genera are now known from there, some so peculiar they have not been placed in the known subfamilies. Six are not known elsewhere in the world. One (the famous marine caddice fly) occurs elsewhere only in Australia. Three others occur also in Australia, but also in other parts of the world, two of them in South America. Five occur in various parts of the world, not in Australia, all in South America.

In the Mayflies New Zealand has at least 6 genera, three peculiar to the islands, two in Australia, one of which is also elsewhere, and one also in North America. In fact, there are no two regions of the world that are geographically so close and entomologically so remote as Australia and New Zealand.

From the above considerations I consider it certain that since the origin of the various orders of insects the continental land-masses have changed entirely. That for a very long period there were two principal continents of very different shape from any that we have at present, and that on one was developed the microtypal fauna, and on the other the Gonwandan; the Brazilian fauna being a more recent development. That the continental changes have favored or prevented dispersal, and these continental changes are the real causes of the peculiarities of faunas, and that proximity has little to do with distribution.

These series of cases of discontinuous distribution are positive evidence of land connections, now broken, of avenues of dispersal, now closed. The surprises of distribution are due not 
only to these land connections, but to the varying places of origin of the various families and genera. Of the insects in any country, some are endemic, some ancient migrants, some more recent migrants.

Our western Raphidid fauna, and absence of Panorpid fauna could be explained in two ways. The Raphidiidæ may have arisen there and migrated to Asia during a land connection, or else if it came from Asia the genus Panorpa was not as abundant in Asia as at the present time.

It will be seen from the foregoing that I consider the insect fauna of the United States to be composed of several elements. I believe there are at least five that can easily be distinguished.

1. Genera which are relicts of a very ancient fauna when land masses were of a different conformation from now. These genera are isolated in our fauna and mostly examples of discontinuous distribution.

One of these series includes the Panorpodes, the Hypochilus, Lachnocrepis, Pristodactyla, Tachopteryx, Hagenius, Tmesiphorus, Midea (section of Anthocharis), Cryptocercus, of the Alleghanian fauna, and doubtlessmany other forms showing relation of Californian and northwest with Europe or Siberia and Japan. Such are Raphidia and Megalomus in Neuroptera. Paraplinthus and Necrophilus are apparently also in this series, and probably Amphizoa and Cephaloon, perhaps Rhinomacer.

In Southern California there is a series of isolated genera which indicate relationship to a very ancient fauna, perhaps connected to the islands of the South Seas. Such are Dinapate, Distaxia, Schizopus (Coleopt.), Oliarces (Neur.), Hubbardia (Arachn.), Timena (Orth.), probably Apioceridæ (Dipt.), and the true Thynnidæ (Hym.), also belong to this group, which stands widely apart from the other insects around it.

In this section we might include any descendants from our Palæozoic insects; I doubt if it is possible to trace any such genera, but our curious Merope tuber may be such a form. The Sialidæ may have arisen within our territory as descendants from Palæozoic forms, but from their present distribution one would suspect Southeastern Asia as their starting place. Our mayflies are probably later migrations; Pteronarcys in Perlidæ may be a derivative of that ancient fauna, but I doubt it; our cockroach fauna is also probably due to later migrations. 
2. Genera representing relicts of probably an ancient invasion from South America, possibly through the West Indies, and after South America had been connected to Africa or to a Pacific continent. These genera are isolated systematically in our fauna, forms that look out of place in our insects, and usually unrepresented in Europe either recent or fossil, at least northern Europe. Such in the Neuroptera are Dilar, Amphientomum, Neoperla, Leptocella, Ganonema.

In Coleoptera, Cupes, Ischalia, our Lymexylon, Othnius, Passalus, Pseudomorphus, Brenthus.

In Hemiptera Henicocephalus, Cylapus, Fulvius, Isometopus, probably Belostoma, Oncerotrachelus, Ceratocombida, Rhagovelia.

In Hymenoptera, Rhinopsis, Pelecinus, Leucospis, Stizus, Pristocera.

In Diptera, Phlebotomus, Nemistrinida, Mydas, Calobata, Sphyracephala, Euxesta, Pyrgota, Blepharoceridce, Stylogaster, Systropus.

In Lepidoptera Feneseca, Thyris, Stenomma, Hemerophilida, IIalesidota.

In Orthoptera, Camptonotus.

It will at once be noted that this element is almost wholly Eastern, and is the element that distinguishes our Eastern States both from the Western States and from Middle and Northern Europe, in fact a tropical element still present with us, and most noticeable in mid-summer.

3. Genera originating in this country from an insect fauna of which 1 and 2 are the relicts. These are genera confined to the United States but whose affinities are rather with South American or Asian insects than with European. I consider that this fauna had a long period of quiet development and became very extensive. The Miocene fossils perhaps represent this fauna.

In Neuroptera, Meleoma, Batisca, Polypsocus, Paraperla, Neophylax, IIeteroplectron, Nannothemis, etc.

In Coleoptera, Sandalus, and many other genera.

In Hemiptera-Sinea, Corythuca, Araphe, Corynocoris, Telamona, Cyrtolobus.

In Hymenoptera, Lyroda, Grotea, Labena, Ceratogastra.

In Diptera, Eclimus, Pelastoneurus, Bittacomorpha, Eutreta, Acrotoxa, Pseudotephritis, Idana. 
In Lepidoptera, Psychomorpha, Acoloithus, our Blastobasidæ.

In Orthoptera, Stenopelmatus, Ceuthophilus, Hippiscus.

In this fauna there was apparently no Cicadidæ, no Mantidæ, nor Mantispidæ, no Mutillidæ, no Ascalaphidæ, no Myrmeleonidæ, no Emesidæ, and few forms of a number of families, now fairly well represented here. These came in later from the South.

4. Genera (and derivative genera) representing the holarctic fauna shoved down by the advance of the ice-sheet, and left well scattered by the retreat of the ice-cap. These are the forms that show the relationship of our insect fauna particularly that of the Eastern States (and British America) with the insects of Northern and Middle Europe. The bulk of many large families belongs to this section, which is most prominent in the spring.

In the Neuroptera, nearly all the Trichoptera, probably Panorpa, Hemerobius, Chrysopa in part, several genera of Odonata as Sympetrum, Aeschna, Cordulia.

In Coleoptera, much of the Carabidæ, Staphylinidæ, etc.

In Hemiptera, many Capsids, Lygæids, and Corixa, Jassidæ, Aradidæ, Corizus, Salda.

In Hymenoptera, many Tenthredinidæ, Ichneumonidæ, Osmia, Bombus, Andrena, Crabro.

In Diptera, many Muscidæ, Anthomyiidæ, Syrphidæ, and genera in nearly all families, as Bombylius, Pipunculus, Syrphus.

In Lepidoptera, many Noctuidæ, Geometridæ, and genera all through the order.

In Orthoptera, Tettix, Gryllus, Decticus, Podisma.

This element is recognized by all entomologists; possibly the lower borders of this Holarctic fauna was contiguous to the previous element, and represented by the Florissant fossils; but I am inclined to believe that these fossils show more relation to a Western fauna rather than to a northern one.

5. Genera representing a comparatively recent influx from the American Tropics, a migration still in progress. To this belong our Mantispidæ, much of Myrmeleonidæ, Ascalaphidæ, Mantidæ, Cicadidæ, Mutillidæ, Brenthidæ, much of the Reduviidæ and other Heteroptera, many genera as Acordulecera, Pepsis, Allochrysa, Resthenia, Haterinia, Callibatis, the Ana- 
phoridæ, Megacilissa, Exomalopsis, Entechuia, Apiomerus, Conorhinus, Anasa, Zelus, Polybia, Schistocerca, Volucella, Schinia.

I doubt not but there are other elements also in our fauna, but I think that these are the most noticeable, and sufficient to show that the Nearctic insect fauna is not a realm, but a conglomeration of several such realms.

The history of each insect is written in its structure. It is therefore possible to discover where each form arose and how it accomplished its distribution. This involves a study of the phylogeny of the genus or family, an investigation of its original home, and the causes that have aided or barred its dispersal; but the essential basis of all is the systematic study of the group 